\title{
PEMBUATAN SOFTWARE "AKSI PINTAR" (ANALISIS KLINIK SANITASI PINTAR) PADA KASUS DIARE (STUDI KASUS KLINIK SANITASI PUSKESMAS 1 KEMBARAN TAHUN 2017)
}

\author{
Wahyu Putriyantari' ${ }^{1)}$, M. Choiroel Anwar ${ }^{2)}$, Mela Firdaust ${ }^{3)}$ \\ Jurusan Kesehatan Lingkungan, Politeknis Kesehatan Kemenkes Semarang, \\ Jl. Raya Baturaden KM 12 Purwokerto, Indonesia
}

\begin{abstract}
Abstrak
Kegiatan klinik sanitasi di Puskesmas 1 Kembaran pada hasil wawancara dan observasi lapangan factor risiko khususnya pada penyakit diare oleh petugas Puskesmas 1 Kembaran masih diolah secara manual sehingga data belum menjadi infromasi kesehatan yang baik untuk perencanaan. Tujuan penelitian ini adalah mengembangkan software pengolahan data klinik sanitasi dengan menggunakan website AKSI PINTAR (Analisis Klinik Sanitasi Pintar) di Puskesmas 1 Kembaran. Jenis penelitian adalah Research and Development (RD). Subyek yang diteliti adalah petugas sanitasi, cara dan hasil pengolahan data klinik sanitasi. Pengumpulan data dilakukan dengan observasi dan wawancara. Analisis yang digunakan pada penelitian ini adalah analisis deskriptif kemudian dibuat pengolahan data dengan computer berbasis website "AKSI PINTAR". Hasil penelitian berupa software untuk pengolahan data klinik sanitasi khususnya penyakit diare yang dapat digunakan untuk pengambilan keputusan maupun perencanaan dengan cepat. Dengan website AKSI PINTAR petugas klinik sanitasi terbantu dalam mengolah data klinik sanitasi menjadi informasi kesehatan dengan cepat dan mudah secara efektif, efisian dan sesuai dengan Permenkes No. 13 Tahun 2015. Pengolahan data klinik sanitasi di Puskesmas 1 Kembaran yang semula hanya meliputi dilakukan dengan cara manual berhasil dirubah menggunakan software berbasis website AKSI PINTAR. Disarankan website AKSI PINTAR dapat diterapkan dalam pelaksanaan pengolahan data klinik sanitasi Puskesmas 1 Kembaran dan dikembangkan untuk digunakan seluruh puskesmas dan Dinas Kesehatan Kabupaten Banyumas.
\end{abstract}

Kata kunci : Klinik Sanitasi; Pengolahan Data; Website AKSI PINTAR

\begin{abstract}
Sanitation clinic at Puskesmas 1 Kembaran, on interview results and observation of risk factors especially diarrhea disease by Puskesmas 1 Kembaran officers is still manually processed, so that the data has not become a good health information for planning. The purpose of this research is to develop sanitation clinic data processing software by using the website "AKSI PINTAR" (Analisis Klinik Sanitasi Pintar) at Puskesmas 1 Kembaran. Type of research is Research and Development (RD). The subjects studied were sanitation officer, way and result of data processing of sanitation clinic. Data collected through interview and observation. Analysis of data used in this research is descriptive analysis and then made data processing with computer based website "AKSI PINTAR" (Analisis Klinik Sanitasi Pintar). The results of research are the form of software for data processing of sanitary clinics, especially diarrhea diseases that can be used for making decision and planning quickly. With the website "AKSI PINTAR", sanitation officer feels helpful in processing sanitation clinic data into health information quickly and easily effectively, efficient and it appropriate with The Regulation of the Minister of Health No. 13 of 2015. The data processing of sanitation clinic at Puskesmas 1 Kembaran which originally manually has been successfully changed using software based on "AKSI PINTAR" website. It is recommended website "AKSI PINTAR" to be applied in the implementation of data processing clinic sanitation Puskesmas 1 Kembaran and developed for the use of all health center and Banyumas Health Office.
\end{abstract}

Keywords : Sanitation Clinic; Data Processing; Website AKSI PINTAR

\footnotetext{
1) E- mail: putriyantariw @ gmail.com

2) E- mail: choirul1960@gmail.com

3) E - mail: melafirdaust@yahoo.co.id
} 


\section{Pendahuluan}

Klinik sanitasi merupakan salah satu bentuk kegiatan pelayanan kesehatan lingkungan yang merupakan bagian dari kegiatan konseling yang dilakukan didalam dan diluar gedung Puskesmas. Klinik Sanitasi merupakan suatu wahana masyarakat dalam mengatasi masalah kesehatan lingkungan untuk pemberantasan penyakit berbasis lingkungan dengan bimbingan, penyuluhan, dan bantuan teknis dari petugas puskesmas. Penyakit berbasis lingkungan seperti penyakit diare, malaria, DBD, kulit, kecacingan, ISPA, TB, keracunan makanan, keracunan pestisida, flu burung, chikungunya dan filariasis (Dinas Kesehatan Propinsi Jawa Tengah, 2005).

Beberapa hambatan yang mungkin ditemui dalam pelaksanaan klinik sanitasi yaitu masih terbatasnya tenaga puskesmas sebagai pelaksana klinik sanitasi, sehingga kegiatan ini belum menjadi prioritas puskesmas. Karena terbatasnya tenaga puskesmas, walaupun kegiatan klinik sanitasi dilaksanakan hanya sekedar dilaksanakan saja. Data informasi masalah penyakit yang ada hanya terkumpul saja tidak diolah menjadi informasi kesehatan yang dapat digunakan untuk perencanaan dan pelaksanaan penanganan masalah kesehatan lingkungan. Khususnya pada penyakit berbasis lingkungan. (Dinas Kesehatan Propinsi Jawa Tengah, 2005).

Pada pelaksanaan kegiatan klinik sanitasi yang ada di Kabupaten Kebumen, petugas klinik sanitasi belum melakukakan monitoring terhadap tindak lanjut dari kegiatan konseling maupun kunjungan rumah, baik terhadap status kesehatan pasien klinik sanitasi maupun morbiditas penyakit berbasis lingkungan. Tidak adanya bukti yang memperkuat kegiatan klinik sanitasi berperan dalam menurunkan morbiditas penyakit menular berbasis lingkungan membuat klinik sanitasi dianggap sebagai program kecil yang tidak punya daya ungkit besar terhadap masalah kesehatan.(http://www.kesehatan.kebumenka b.go.id )

Puskesmas 1 Kembaran merupakan puskesmas yang berada di Jalan Raya Sokaraja-Sumbang RT 06 RW 02 Kecamatan Kembaran, Kabupaten Banyumas, Jawa Tengah. Pelayanan promosi kesehatan lingkungan di Puskesmas 1 Kembaran salah satunya adalah melaksanakan kegiatan konseling meliputi kegiatan klinik sanitasi. Kegiatan ini dilakukan oleh petugas sanitarian yang berada di puskesmas dan dilakukan seminggu dua kali pada hari Selasa dan Rabu.

Pada pengelolaan data klinik sanitasi khususnya pada data penyakit diare yang dilakukan di Puskesmas 1 Kembaran masih menggunakan sistem manual. Hal ini tentunya membutuhkan waktu yang lama dalam pengisian formulir dan data yang tertulis pada buku laporan klinik sanitasi terkadang tidak dapat terbaca dengan jelas oleh petugas. Formulir pada buku laporan klinik sanitasi di Puskesmas 1 Kembaran masih belum sesuai dengan Permenkes No. 13 Tahun 2015 tentang Penyelenggaraan Pelayanan Kesehatan Lingkungan di Puskesmas. Data pasien diare yang sudah masuk pada klinik sanitasi selanjutnya oleh petugas tidak dilakukan tindak lanjut terhadap data yang ada. Petugas juga mengalami kesulitan dalam mencari data yang digunakan untuk kunjungan lapangan sebagai tindak lanjut klinik sanitasi.

Salah satu upaya untuk mengatasi masalah pengolahan data tersebut adalah menerapkan sistem pengolahan data berbasis computer dengan bahasa pemograman MySQL. MySQL (My Structure Query Language) sebuah manajemen sistem database server yang mampu menangani beberapa user, yaitu mampu menangani beberapa instruksi sekaligus dari beberapa user dalam satu waktu. Dan MySQL merekam semua data user di dalam sistemnya dalam table user. Keuntungan menyimpan data di database adalah kemudahannya dalam penyimpanan dan menampilkan data karena dalam bentuk table. Diharapkan dengan menggunakan bahasa pemograman MySQL dapat mempermudah dalam pengolahan data. (Anhar, 2010)

Tujuan penelitian adalah mengaplikasikan pengolahan data klinik sanitasi penyakit diare dengan menggunakan website AKSI PINTAR (Analisis Klinik Sanitasi Pintar) di Puskesmas 1 Kembaran.

\section{Bahan dan Metode}

Jenis penelitian adalah Research and Development $(R D)$ yaitu metode penelitian yang digunakan untuk menghasilkan atau mengembangkan produk. Mengembangkan instrument klinik sanitasi manual menjadi software yang berbasis website AKSI PINTAR. Subyek yang diteliti adalah petugas sanitasi, cara dan hasil pengolahan data klinik sanitasi. Pengumpulan data dilakukan dengan observasi dan wawancara. Analisis yang digunakan pada penelitian ini adalah analisis deskriptif kemudian dibuat pengolahan data dengan computer berbasis website "AKSI PINTAR" (Analisis Klinik Sanitasi Pintar) berbasis pengolahan data MySQL. 
III. Hasil dan Pembahasan

A. Gambaran Umum Penelitian

Program kerja yang dilaksanakan di Puskesmas I Kembaran pada tahun 2017 adalah meliputi kegiatan upaya kesehatan masyarakat esensial dan upaya kesehatan masyarakat pengembangan. Salah satu upaya kesehatan masyarakat esensial yang ada di Puskesmas 1 Kembaran adalah pelayanan kesehatan lingkungan.

Kegiatan klinik sanitasi di Puskesmas 1 Kembaran dilaksanakan baik di dalam maupun di luar gedung puskesmas (kunjungan lapangan). Pelaksanaan klinik sanitasi di dalam gedung dilakukan seminggu dua kali pada hari Selasa dan Rabu. Selain hari itu semua data penyakit berbasis lingkungan hanya akan masuk ke data rekam medis puskesmas atau SIMPUS (Sistem Informasi Puskesmas) yang kemudian akan direkap oleh tenaga surveilans. Pelaksanaan klinik sanitasi di luar gedung (kunjungan lapangan) sebagai tindak lanjut dari hasil wawancara konseling di dalam gedung biasanya dilakukan pada hari Jumat atau pada hari yang sudah disepakati. Kegiatan ini dilakukan oleh petugas klinik sanitasi yang berada di puskesmas. Namun apabila petugas klinik sanitasi sedang melakukan dinas luar, kegiatan klinik sanitasi biasanya tidak berjalan.

Sarana dan prasarana yang dimiliki adalah ruang promosi kesehatan, sanitarian kit dan SPAL (Sarana Pembuangan Air Limbah). Program kesehatan lingkungan yang berjalan di Puskesmas 1 Kembaran yaitu pendataan sarana sanitasi dasar, inspeksi kesehatan lingkungan, pengambilan sampel air dan makanan, kegiatan pemicuan, orientasi natural leader, kegiatan klinik sanitasi, pendataan rumah sehat dan kunjungan rumah. Semua program kesehatan lingkungan berjalan menggunakan dana BOK (Bantuan Operasional Kesehatan).

B. Sistem Pengolahan Data Klinik Sanitasi Penyakit Diare Dengan Website AKSI PINTAR (Analisis Klinik Sanitasi Pintar)

Website AKSI PINTAR (Analisis Klinik Sanitasi Pintar) merupakan website yang berfungsi untuk membantu petugas klinik sanitasi dalam mengolah semua data klinik sanitasi yang meliputi data penyakit berbasis lingkungan menjadi sebuah informasi kesehatan.
Dalam penelitian ini berfokus pada pengolahan data klinik sanitasi penyakit diare yang merupakan penyakit berbasis lingkungan paling dominan di Puskesmas 1 Kembaran.

Sistem pengolahan data klinik sanitasi penyakit diare menggunakan website AKSI PINTAR terdiri dari beberapa tahap. Yakni input, proses dan output. Pada tahap input merupakan proses pemasukan data pasien klinik sanitasi berupa biodata pasien dan formulir pertanyaan yang berisi factor resiko kejadian diare yang ada pada Menu Pemeriksaan. Pada tahap proses meliputi proses editing, coding dan entering yang dilakukan oleh PHP dan MySQL. Data yang terinput akan diolah dan tersimpan pada hosting (tempat penyimpanan online). Kemudian pada tahap output merupakan hasil dari data yang telah diolah menjadi informasi. Pada website AKSI PINTAR, hasil data yang meliputi gambaran factor resiko kejadian diare, perilaku dan lingkungan pasien diolah menjadi table, diagram batang, diagram pie dan gambar (foto). Tahap output pada website AKSI PINTAR ada pada Menu Data Pasien, Menu Daftar Pemeriksaan, Menu Daftar Jumlah Kasus, Menu Grafik Wilayah, dan Dashboard.

Untuk mengakses website AKSI PINTAR (Analisis Klinik Sanitasi Pintar) pada laptop atau computer petugas klinik sanitasi, terlebih dahulu petugas mengetik di halaman pencaharian browser yaitu https://banyu.center/client/sanitasi . Maka akan muncul tampilan halaman website AKSI PINTAR seperti pada gambar 4.1.

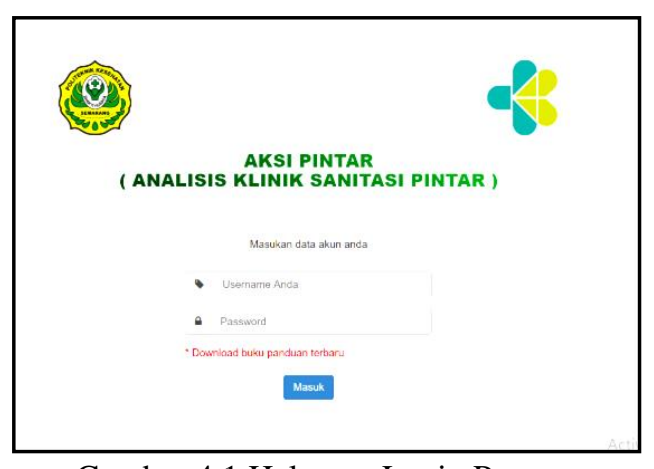

Gambar 4.1 Halaman Login Pengguna Website AKSI PINTAR

(Analisis Klinik Sanitasi Pintar) 


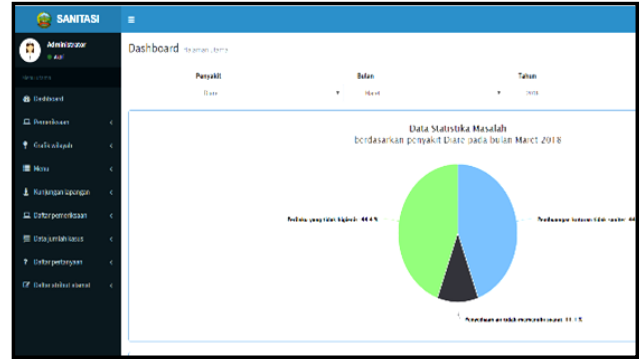

Gambar 4.2 Halaman Utama

Website AKSI PINTAR

(Analisis Klinik Sanitasi Pintar)

1. Tahap Input

a. Input Data Pemeriksaan

Input data pemeriksaan merupakan kegiatan input data dari kegiatan klinik sanitasi yang dilakukan di dalam gedung Puskesmas 1 Kembaran. Biasanya kegiatan input data ini dilakukan menggunakan leptop atau computer petugas klinik sanitasi

Pilih Menu Pemeriksaan pada bagian Menu Utama, kemudian pilih pemeriksaan. Maka akan muncul tampilan halaman seperti pada gambar 4.3. Petugas terlebih dahulu memilih kategori pasien, apakah pasien baru atau lama

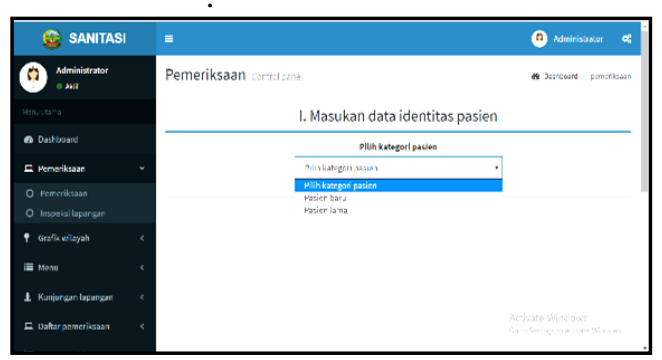

Gambar 4.3 Tampilan Halaman Pemeriksaan Pada Website AKSI PINTAR

(Analisis Klinik Sanitasi Pintar)

Pada katagori pasien baru, pasien tersebut belum pernah dirujuk ke ruang klinik sanitasi dan datanya belum pernah di input kedalam website. Sehingga pasien tersebut memiliki kode pasien baru. Petugas harus mengisi dengan lengkap biodata umum pasien yang meliputi nama pasien, jenis kelamin, umur pasien, nama kepala keluarga, pekerjaan pasien, penyakit yang diderita oleh pasien, provinsi, kabupaten, kecamatan, kelurahan atau desa dan alamat pasien. Setelah semua data terisi petugas dapat memilih pilihan Lanjut pada halaman website.

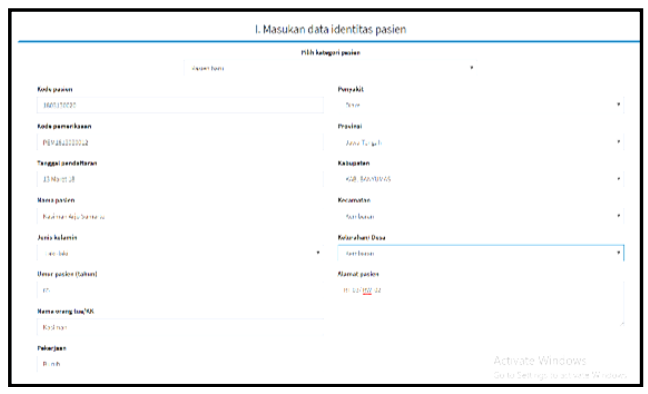

Gambar 4.4 Tampilan Halaman Identitas Pasien Baru Pada Website AKSI PINTAR (Analisis Klinik Sanitasi Pintar)

Pada katagori pasien lama, pasien tersebut sudah pernah dirujuk ke ruang klinik sanitasi dan datanya sudah pernah di input kedalam website. Sehingga pasien tersebut sudah memiliki kode pasien. Petugas hanya mengisi kode pasien tersebut dan penyakit yang diderita oleh pasien tersebut. Setelah semua data terisi petugas dapat memilih pilihan Lanjut pada halaman website.

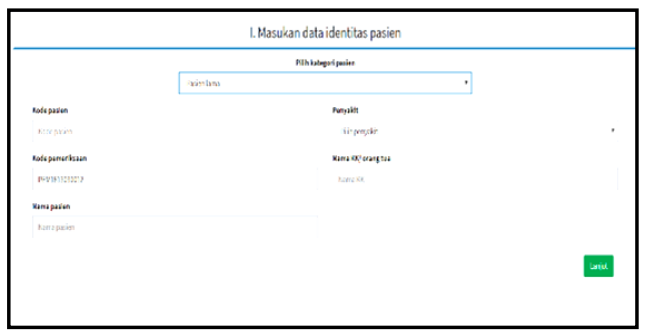

Gambar 4.5 Tampilan Halaman Identitas Pasien Lama Pada Website AKSI PINTAR (Analisis Klinik Sanitasi Pintar)

Setelah data umum pasien terisi, maka akan muncul tampilan halaman formulir identifikasi masalah lingkungan dan perilaku seperti pada gambar 4.6. Petugas melakukan wawancara terhadap pasien mengenai penyakit yang dideritanya untuk mengetahui penyebabnya. Pada tampilan formulir identifikasi masalah lingkungan dan perilaku sudah 
berisi semua pertanyaan mengenai factor resiko kejadian diare. Petugas hanya tinggal melakukan wawancara sesuai dengan pertanyaan yang muncul pada tampilan formulir kemudian petugas memilih jawaban yang ada pada tampilan formulir sesuai dengan jawaban pasien. Apabila jawaban pasien tidak ada pada pilihan jawaban, petugas dapat menambah jawaban dengan memilih tambah jawaban. Setelah itu pilih lanjut.

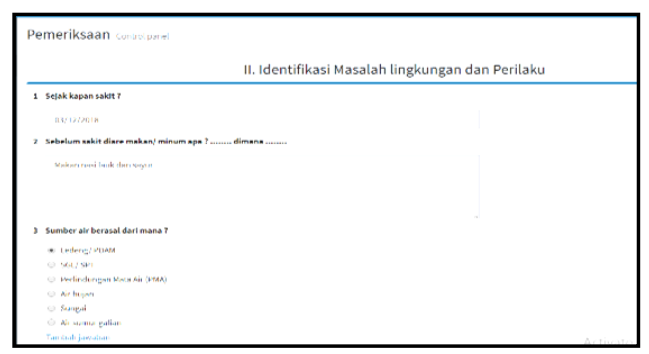

Gambar 4.6 Tampilan Halaman Identifikasi Masalah Lingkungan dan Perilaku Pada Website AKSI PINTAR

(Analisis Klinik Sanitasi Pintar)

Setelah pilih lanjut, makan akan muncul tampilan halaman review hasil pemeriksaan yang sudah petugas lakukan.

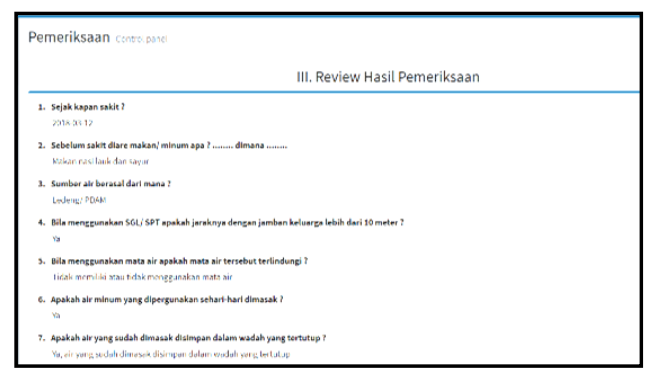

Gambar 4.7 Tampilan Halaman Review Hasil Pemeriksaan Pada Website AKSI PINTAR (Analisis Klinik Sanitasi Pintar)

Pilih lanjut pada tampilan halaman review hasil pemeriksaan. Akan muncul tampilan halaman kesimpulan pemeriksaan seperti pada gambar 4.8. Pada halaman ini petugas mengisi dugaan penyebab pasien terkena penyakit tersebut sesuai dengan hasil wawancara identifikasi masalah lingkungan dan perilaku. Kemudian pilih saran yang sesuai dengan penyebabnya. Petugas juga dapat menambahkan saran dengan mengklik tambah saran kemudian simpan. Pilih rencana tindak lanjut apakah pasien setuju atau tidak setuju untuk dilakukan kunjungan ke rumah pasien. Apabila pasien setuju maka akan muncul pilihan tanggal kunjungan lapangan yang dapat diisi sesuai dengan kesepakatan antara pasien dan petugas. Pilih simpan untuk menyimpan semua hasil wawancara.

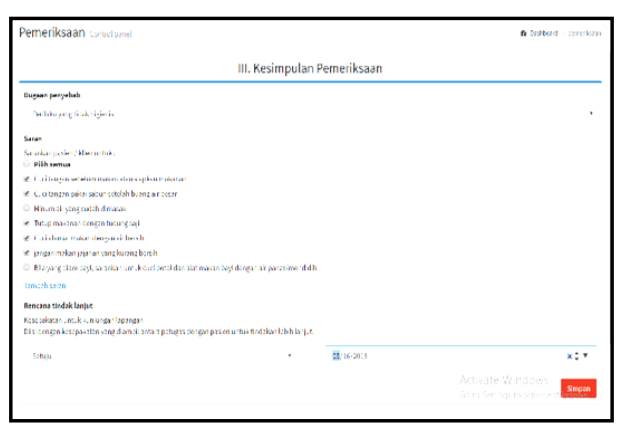

Gambar 4.8 Tampilan Halaman

Kesimpulan Pemeriksaan Pada Website

AKSI PINTAR

(Analisis Klinik Sanitasi Pintar)

Setelah semua formulir pemeriksaan terisi dan sudah tersimpan, akan muncul tampilan halaman riwayat pemeriksaan seperti pada gambar 4.9 dan 4.10. Halaman riwayat pemeriksaan berisi detail kuesioner pemeriksaan dan detail kesimpulan pemeriksaan. Untuk melakukan pemeriksaan kembali, petugas dapat memilih Menu Pemeriksaan kembali.

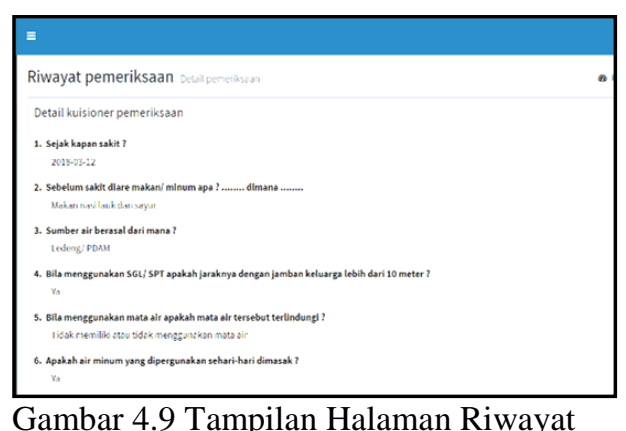

Gambar 4.9 Tampilan Halaman Riwayat

Pemeriksaan - Detail Kuesioner

Pemeriksaan Pada Website AKSI PINTAR

(Analisis Klinik Sanitasi Pintar) 


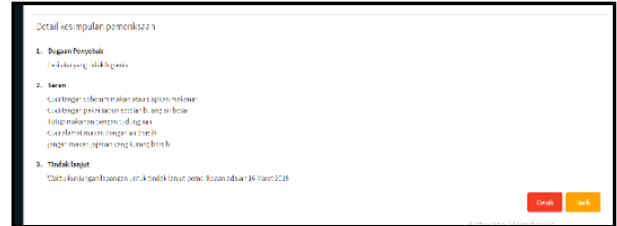

Gambar 4.10 Tampilan Halaman Riwayat Pemeriksaan - Detail Kesimpulan

Pemeriksaan Pada

Website AKSI PINTAR

(Analisis Klinik Sanitasi Pintar)

b. Input Data Inspeksi Lapangan Input data inspeksi lapangan merupakan kegiatan input data dari kegiatan klinik sanitasi yang dilakukan di luar gedung Puskesmas 1 Kembaran. Karena inspeksi lapangan dilakukan di luar gedung, maka kegiatan penginputan data dilakukan menggunakan handphone perugas sanitaran.

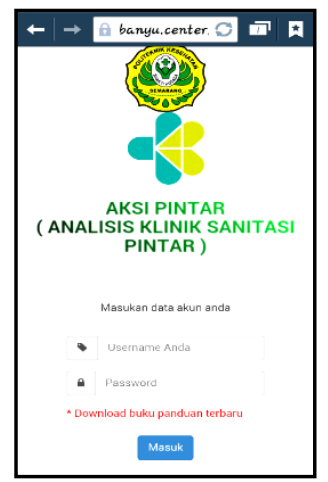

Gambar 4.11 Tampilan

Halaman Login Pengguna

Website AKSI PINTAR

(Analisis Klinik Sanitasi

Pintar) Menggunakan

Handphone

Pilih Menu Pemeriksaan kemudian pilih Menu Inspeksi Lapangan. Maka akan muncul tampilan halaman seperti gambar 4.12. Petugas harus terlebih dahulu mengisi kode pemeriksaan pasien sesuai dengan kode pada pemeriksaan yang sebelumnya telah dilakukan di puskesmas. Setelah kode pemeriksaan terisi, secara otomastis data umum pasien yang dikunjungi sudah terinput kemudian pilih lanjut.

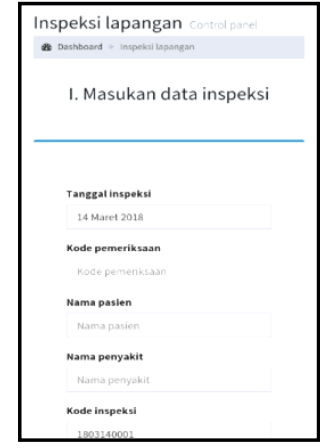

Gambar 4.12 Tampilan

Halaman Data Pasien Inspeksi Lapangan Website AKSI

PINTAR (Analisis Klinik

Sanitasi Pintar) Menggunakan Handphone

Setelah data umum pasien terinput, maka akan muncul tampilan formulir pertanyaan inspeksi lapangan. Isi semua pertanyaan formulir sesuai dengan hasil inspeksi dengan memilih maupun menambah jawaban. Setelah semua terisi pilih lanjut.

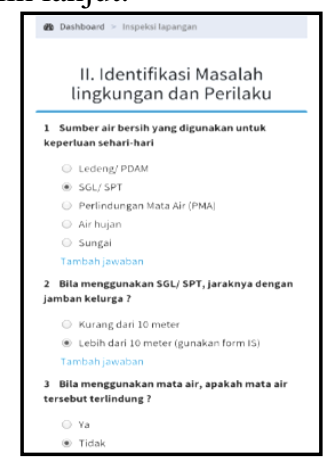

Gambar 4.13 Tampilan

Halaman Identifikasi Masalah Lingkungan dan Perilaku Pada Inspeksi Lapangan Website AKSI PINTAR

(Analisis Klinik Sanitasi

Pintar) Menggunakan Handphone

Akan muncul tampilan review hasil inspeksi lapangan. Pilih lanjut. 


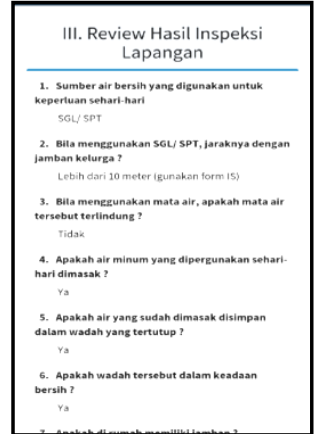

Gambar 4.14 Tampilan

Halaman Review Hasil Inspeksi Lapangan Website AKSI PINTAR (Analisis

Klinik Sanitasi Pintar)

Menggunakan Handphone

Akan muncul tampilan memasukan data foto kondisi lingkungan pasien seperti pada gambar 4.14. Petugas dapat melampirkan maksimal 5 foto atau tidak menambah foto pada inspeksi lapangan. Petugas dapat langsung mengambil gambar kondisi atau mengambil gambar dari galery petugas. Kemudian pilih simpan dan pilih lanjut setelah foto tersimpan.

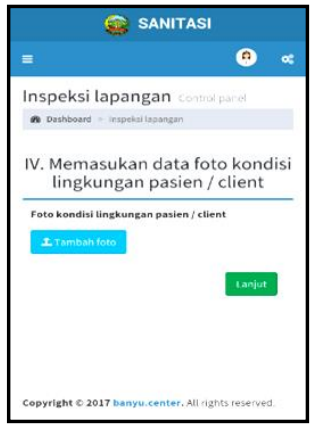

Gambar 4.15 Tampilan

Halaman Memasukan Data Foto Kondisi Lingkungan

Pasien Pada Website AKSI

PINTAR (Analisis Klinik

Sanitasi Pintar) Menggunakan Handphone

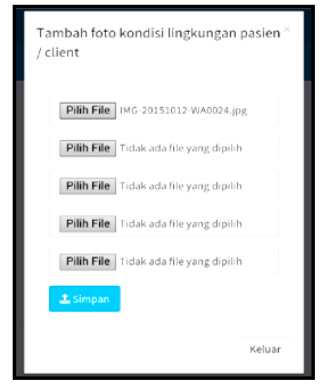

Gambar 4.16 Tampilan Halaman Memasukan Data Foto Kondisi Lingkungan Pasien Pada Website AKSI PINTAR (Analisis Klinik Sanitasi Pintar) Menggunakan Handphone

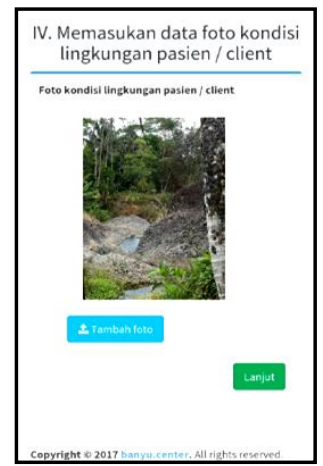

Gambar 4.17 Tampilan

Halaman Memasukan Data

Foto Kondisi Lingkungan

Pasien Pada Website AKSI

PINTAR (Analisis Klinik Sanitasi Pintar) Menggunakan Handphone

Muncul tampilan kesimpulan inspeksi lapangan seperti pada gambar 4.18. Disini petugas mengisi dugaan penyebab pasien terkena penyakit, saran yang diberikan sesuai dengan penyebabnya dan rencana tindak lanjut yang akan dilakukan oleh petugas. Setelah itu pilih simpan. 


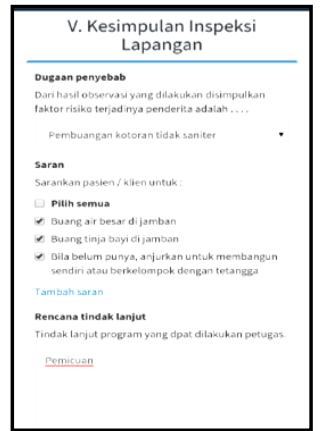

Gambar 4.18 Tampilan Halaman Kesimpulan Inspeksi Lapangan Pada Website AKSI PINTAR

(Analisis Klinik Sanitasi Pintar) Menggunakan Handphone

Setelah inspeksi lapangan selesai muncul review pemeriksaan inspeksi lapangan. Untuk melakukan pemeriksaan kembali, petugas dapat memilih Menu Pemeriksaan kembali.

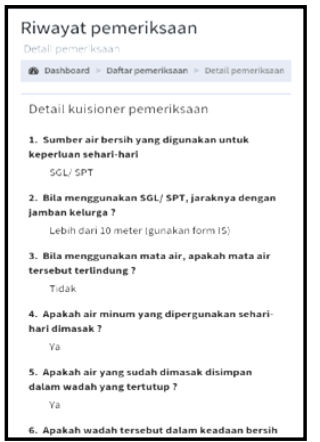

Gambar 4.19 Tampilan

Halaman Detail Kuesioner

Pemeriksaan Pada Website

AKSI PINTAR (Analisis

Klinik Sanitasi Pintar)

Menggunakan Handphone

2. Tahap Proses

Pada tahap ini, proses pengolahan data dilakukan otomatis pada website AKSI PINTAR. Semua data klinik sanitasi yang sudah terinput akan diproses oleh bahasa server yaitu PHP yang mengolah database MySQL. Data juga sudah tersimpan pada hosting. Hosting merupakan tempat penyimpan data secara online.

\section{Tahap Output}

a. Menu Data Pasien

Pada menu ini merupakan data rekam medis pasien klinik sanitasi. Berisi tentang data umum pasien dan riwayat pemeriksaan yang sudah dilakukan. Dengan menu ini, petugas klinik sanitasi dapat melihat data umum setiap pasien yang berupa nama, umur, jenis kelamin, pekerjaan, nama kepala keluarga pasien dan alamat pasien. Petugas juga dapat melihat formulir riwayat pemeriksaan yang telah dilakukan pada pasien tersebut.

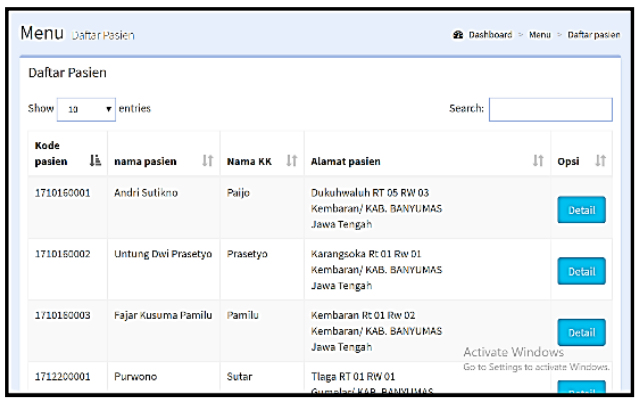

Gambar 4.20 Tampilan Halaman Daftar

Pasien Pada Website AKSI PINTAR

(Analisis Klinik Sanitasi Pintar)

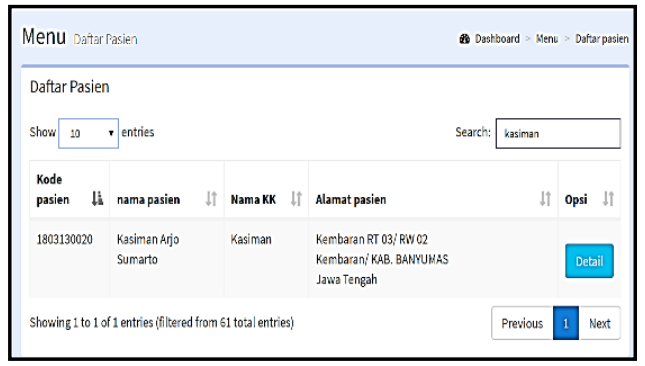

Gambar 4.21 Tampilan Halaman Data Pasien Yang Dicari Pada Daftar Pasien Website AKSI PINTAR (Analisis Klinik Sanitasi Pintar)

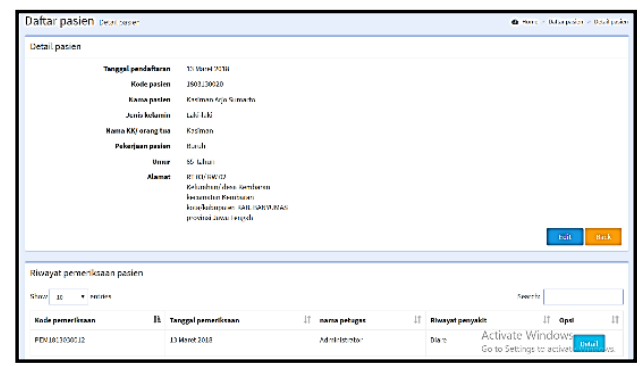

Gambar 4.22 Tampilan Halaman Detail

Data Pasien Yang Dicari Pada Daftar

Pasien Website AKSI PINTAR (Analisis Klinik Sanitasi Pintar) 


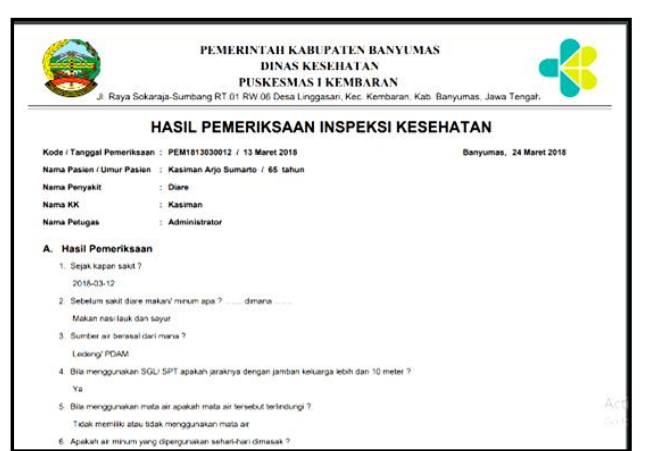

Gambar 4.23 Tampilan Halaman Hasil Pemeriksaan Website AKSI PINTAR

(Analisis Klinik Sanitasi Pintar)

b. Menu Daftar Pemeriksaan

1) Daftar Pemeriksaan

Berisi semua data pemeriksaan yang dilakukan di dalam gedung puskesmas. Terdiri dari data secara keseluruhan, data yang hanya berisi daftar pemeriksaan pada hari tersebut (hari ini) dan cetak keseluruhan untuk pelaporan.

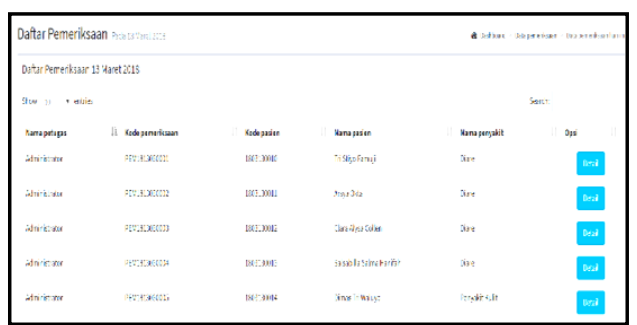

Gambar 4.24 Tampilan Halaman Daftar Pemeriksaan Pada Hari Ini Website AKSI PINTAR (Analisis Klinik Sanitasi Pintar)

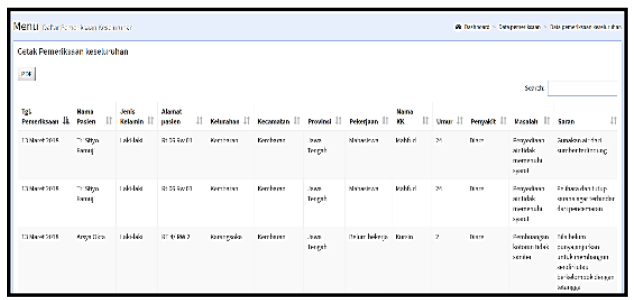

Gambar 4.25 Tampilan Halaman Cetak Pemeriksaan Keseluruhan Pada Website AKSI PINTAR (Analisis Klinik Sanitasi Pintar)

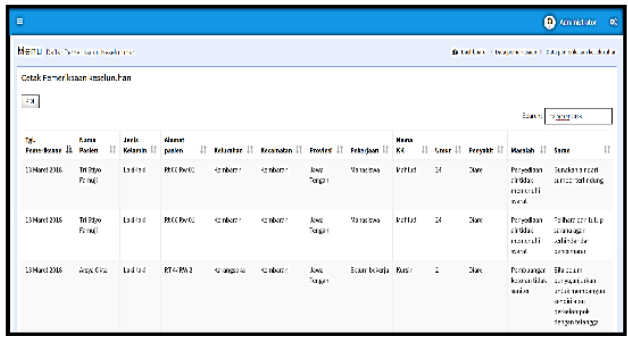

Gambar 4.26 Tampilan Halaman Cetak

Pemeriksaan Keseluruhan - Tanggal 13

Maret 2018 Pada Website AKSI PINTAR

(Analisis Klinik Sanitasi Pintar)

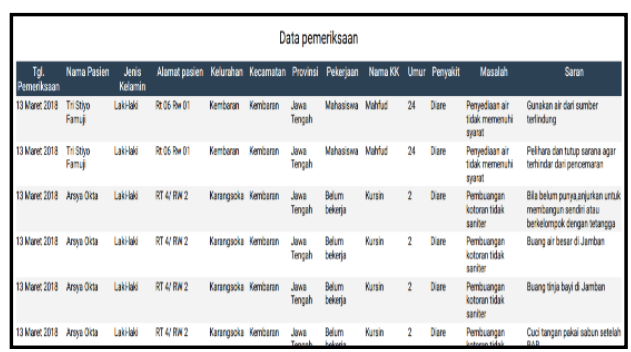

Gambar 4.27 Tampilan Halaman PDF Data

Pemeriksaan - Tanggal 13 Maret 2018

Pada Website AKSI PINTAR (Analisis

Klinik Sanitasi Pintar)

2) Inspeksi Lapangan

Pada menu daftar pemeriksaan inspeksi lapangan, petugas dapat melihat data pemeriksaan inspeksi lapangan yang sudah dilakukan baik secara keseluruhan maupun yang pada hari itu telah dilakukan. Petugas dapat melihat hasil inspeksi lapangan dengan memilih opsi detail dan dapat melihat lampiran foto inspeksi lapangan dengan memilih opsi image. Data pemeriksaan inspeksi lapangan dapat disimpan maupun dicetak oleh petugas.

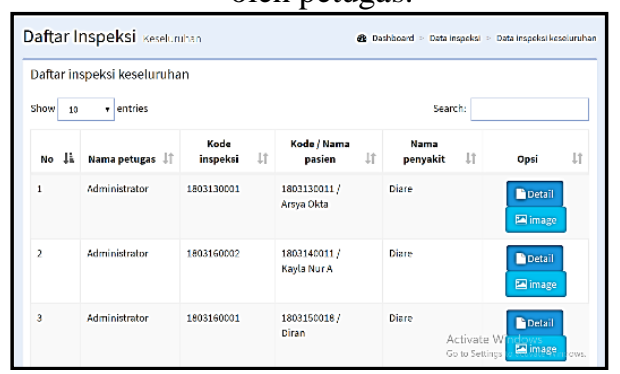

Gambar 4.28 Tampilan Halaman Daftar Inspeksi Lapangan Keseluruhan Pada Website AKSI PINTAR (Analisis Klinik Sanitasi Pintar) 


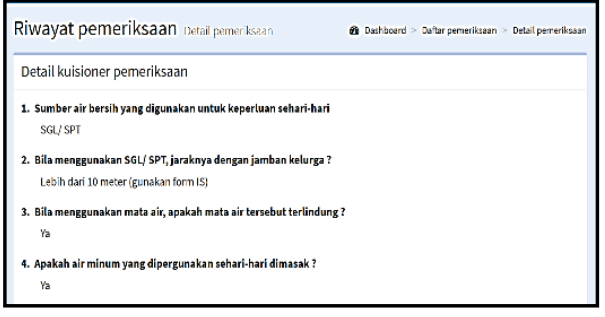

Gambar 4.29 Tampilan Halaman Detail Riwayat Pemeriksaan Inspeksi Lapangan Rumah Pasien Pada Website AKSI PINTAR (Analisis Klinik Sanitasi Pintar)

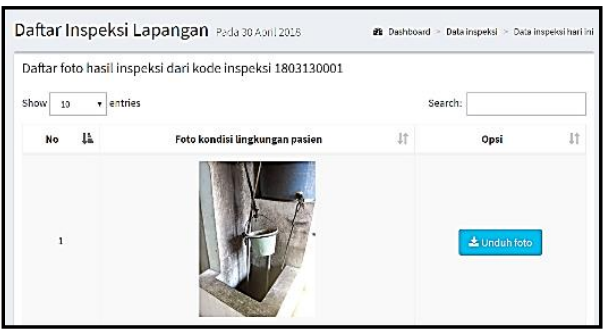

Gambar 4.30 Tampilan Halaman Foto Hasil Inspeksi Lapangan Rumah Pasien Pada Website AKSI PINTAR (Analisis Klinik Sanitasi Pintar)

c. Menu Data Jumlah Kasus

1) Data Jumlah Kasus Pemeriksaan

Pada menu ini, petugas dapat melihat data jumlah kasus berdasarkan pemeriksaan penyakit dan masalah pasiennya. Pada menu data jumlah kasus pemeriksaan berdasarkan penyakitnya dan masalahnya, petugas dapat meilhat data secara keseluruhan, data pada hari ini dan data per periode.

Pada menu keseluruhan, petugas memilih tahun untuk ditampilkan data secara keseluruhan dari bulan Januari sampai dengan bulan Desember. Pada menu hari ini, data yang muncul hanya data jumlah kasus yang didapat pada hari tersebut. Dan pada menu per periode, petugas dapat melihat data jumlah kasus pemeriksaan penyakit dari waktu tertentu sampai dengan waktu tertentu. Semua data yang muncul pada menu diatas dapat petugas simpan dan cetak dengan memilih kolom hijau Cetak Data.

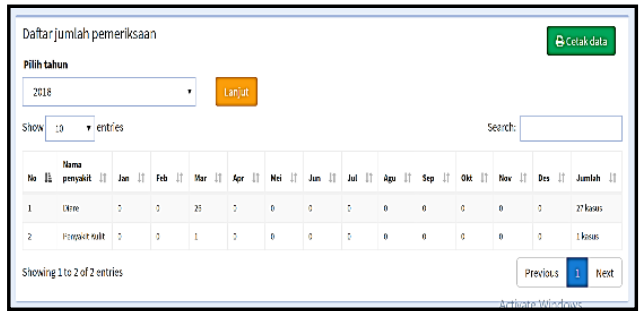

Gambar 4.31 Tampilan Halaman

Data Jumlah Kasus Pemeriksaan

Penyakit Secara Keseluruhan Pada

Website AKSI PINTAR (Analisis Klinik Sanitasi Pintar)

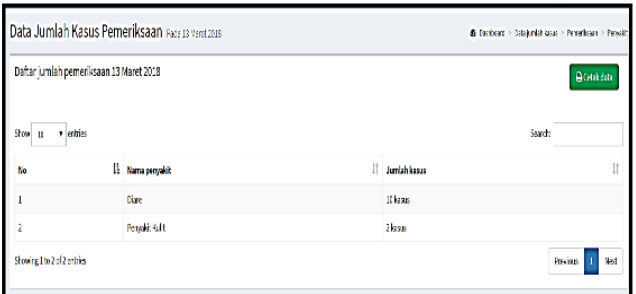

Gambar 4.32 Tampilan Halaman

Data Jumlah Kasus Pemeriksaan

Penyakit Hari Ini Pada Website AKSI PINTAR (Analisis Klinik Sanitasi Pintar)

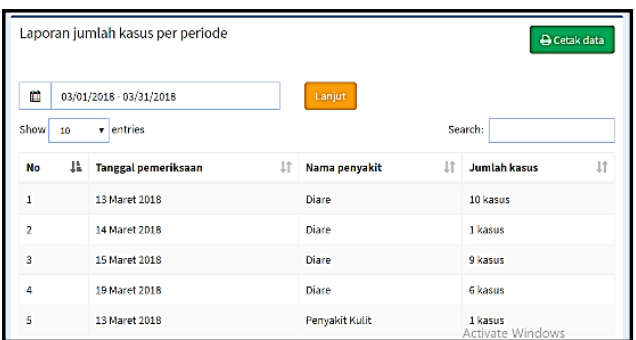

Gambar 4.33 Tampilan Halaman

Data Jumlah Kasus Pemeriksaan

Penyakit Per Periode Pada Website AKSI PINTAR (Analisis Klinik Sanitasi Pintar)

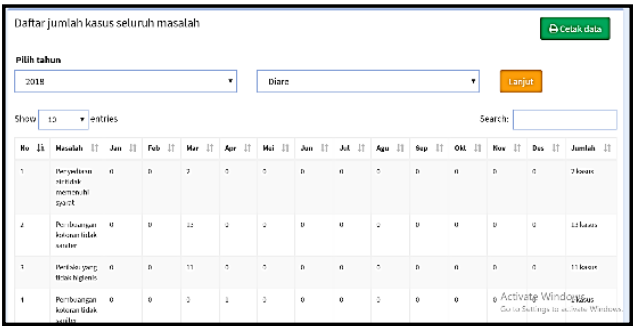

Gambar 4.34 Tampilan Halaman

Data Jumlah Kasus Pemeriksaan

Masalah Secara Keseluruhan Pada Website AKSI PINTAR (Analisis Klinik Sanitasi Pintar) 


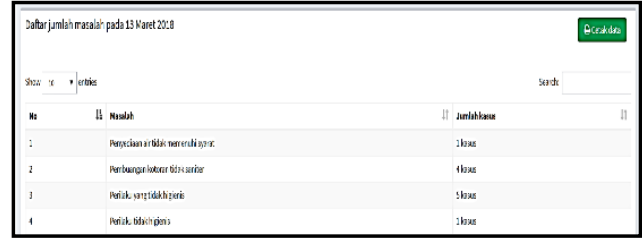

Gambar 4.35 Tampilan Halaman Data Jumlah Kasus Pemeriksaan Masalah

Pada Hari Ini Pada Website

AKSI PINTAR (Analisis Klinik Sanitasi Pintar)

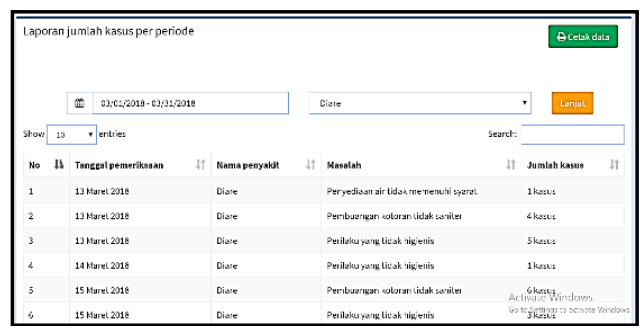

Gambar 4.36 Tampilan Halaman Data

Jumlah Kasus Pemeriksaan Masalah

Per Periode Pada Website AKSI

PINTAR (Analisis Klinik Sanitasi Pintar)

2) Data Jumlah Kasus Inspeksi Lapangan Pada menu ini, petugas dapat melihat data jumlah kasus berdasarkan kegiatan inspeksi lapangan yang sudah dilakukan. petugas dapat melihat data jumlah kasus inspeksi lapangan secara keseluruhan dan per periode (waktu tertentu).

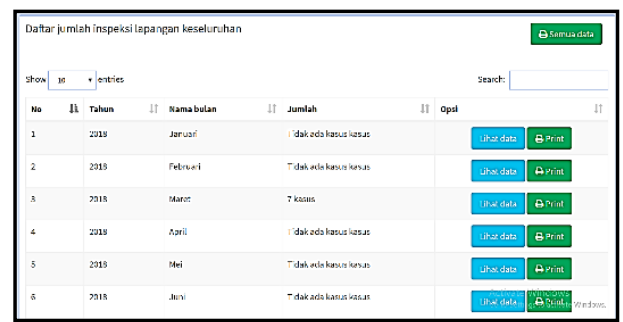

Gambar 4.37 Tampilan Halaman

Data Jumlah Kasus Inspeksi

Lapangan Secara Keseluruhan Pada Website AKSI PINTAR (Analisis Klinik Sanitasi Pintar)

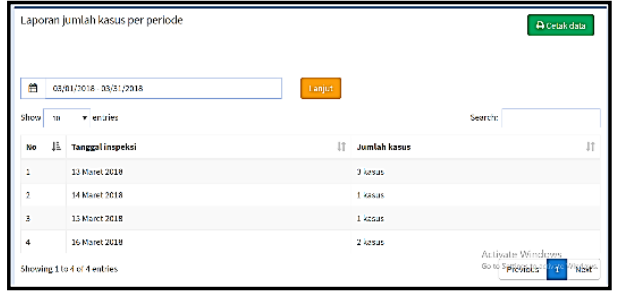

Gambar 4.38 Tampilan Halaman Data Jumlah Kasus Inspeksi

Lapangan Per Periode Pada Website AKSI PINTAR (Analisis Klinik Sanitasi Pintar)

3) Data Jumlah Kasus Pada Suatu Wilayah

Pada menu data jumlah kasus berdasarkan wilayah, petugas dapat mengetahui jumlah kasus penyakit dan masalah per wilayah secara keseluruhan, per periode dan pada waktu 5 tahun terakhir. Data tersebut bisa disimpan maupun dicetak.

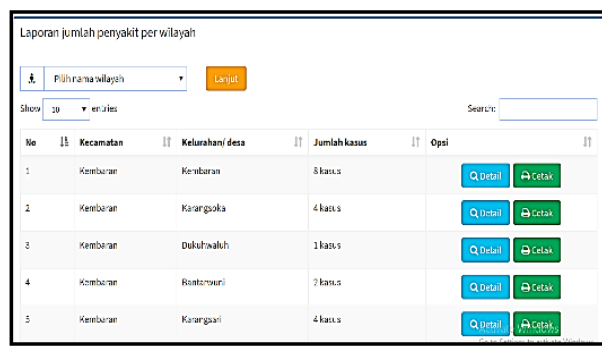

Gambar 4.39 Tampilan Halaman

Data Jumlah Kasus Wilayah -

Penyakit Secara Keseluruhan Pada Website AKSI PINTAR (Analisis Klinik Sanitasi Pintar)

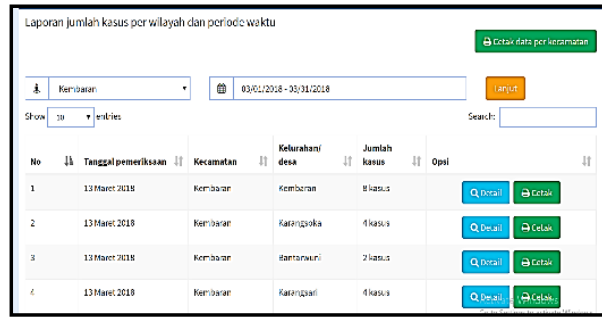

Gambar 4.40 Tampilan Halaman Data Jumlah Kasus Wilayah Penyakit Per Periode Pada Website AKSI PINTAR (Analisis Klinik Sanitasi Pintar) 


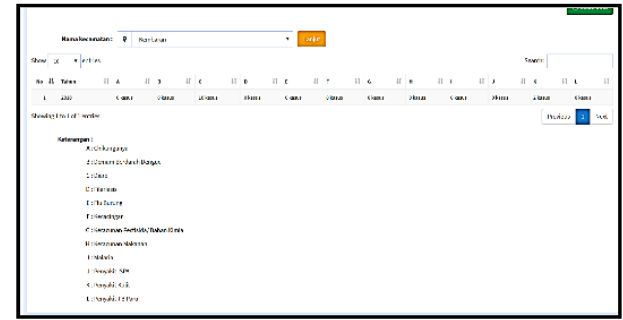

Gambar 4.41 Tampilan Halaman Data

Jumlah Kasus Wilayah - Penyakit 5

Tahun Terakhir Tingkat Kecamatan Pada Website AKSI PINTAR (Analisis Klinik Sanitasi Pintar)

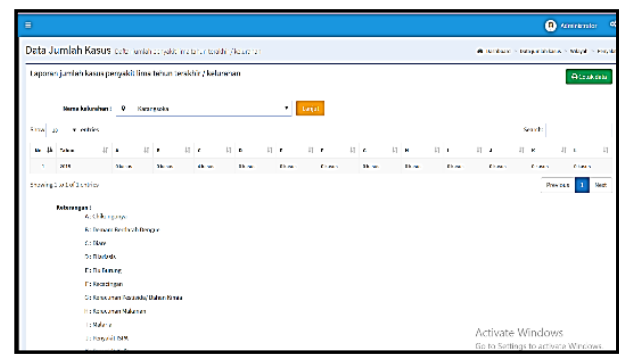

Gambar 4.42 Tampilan Halaman Data

Jumlah Kasus Wilayah - Penyakit 5

Tahun Terakhir Tingkat Kelurahan Pada Website AKSI PINTAR

(Analisis Klinik Sanitasi Pintar)

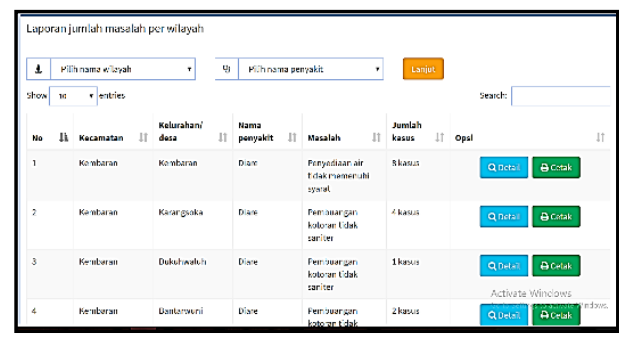

Gambar 4.43 Tampilan Halaman Data

Jumlah Kasus Wilayah - Masalah

Secara Keseluruhan Pada Website AKSI PINTAR

(Analisis Klinik Sanitasi Pintar)

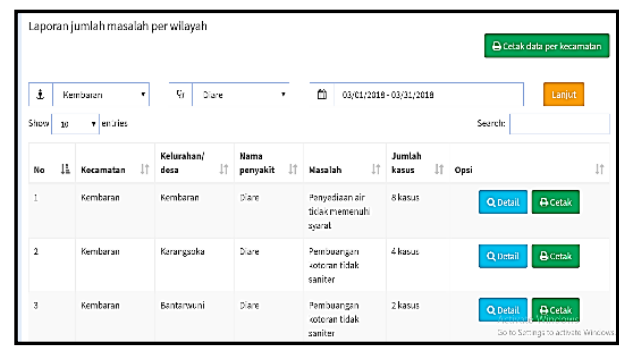

Gambar 4.44 Tampilan Halaman Data Jumlah Kasus Wilayah - Masalah Per Periode Pada Website AKSI PINTAR

(Analisis Klinik Sanitasi Pintar)

d. Menu Grafik Wilayah

Menu ini berfungsi untuk menampilkan tampilan data jumlah kasus map berdasarkan nama penyakit bulan dan tahunnya yang petugas pilih sesuai dengan daerah yang terdapat kasus berdasarkan nama penyakitnya. Petugas hanya tinggal memilih menu grafik wilayah.

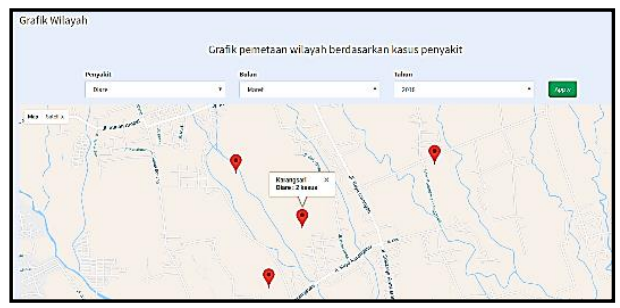

Gambar 4.45 Tampilan Halaman Grafik Wilayah Pada Website AKSI PINTAR (Analisis Klinik Sanitasi Pintar)

e. Dashboard

Dashboar merupakan menu tampilan awal halaman website AKSI PINTAR. Pada halaman ini terdapat tampilan diagram batang dan pie. Diagram pie merupakan diagram tentang statistika data pemeriksaan berdasarkan penyebab masalah dari jenis penyakit yang ditentukan. Sedangkan diagram batang yaitu statistika data kasus berdasarkan penyakit perbulan dan pertahun. Diagram tersebut dapat petugas simpan maupun cetak sesuai dengan kebutuhan petugas.

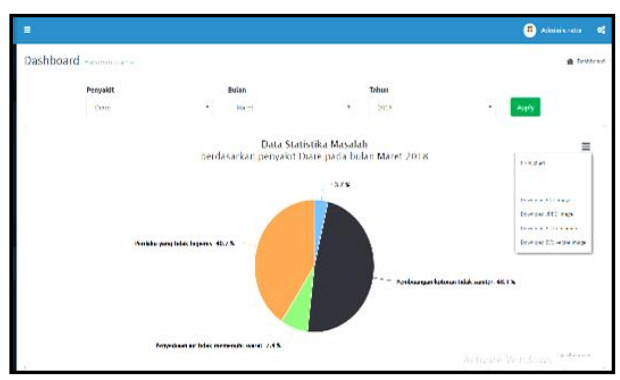

Gambar 4.46 Tampilan Halaman Dashboard - Grafik Pie Pada Website AKSI PINTAR (Analisis Klinik Sanitasi Pintar) 


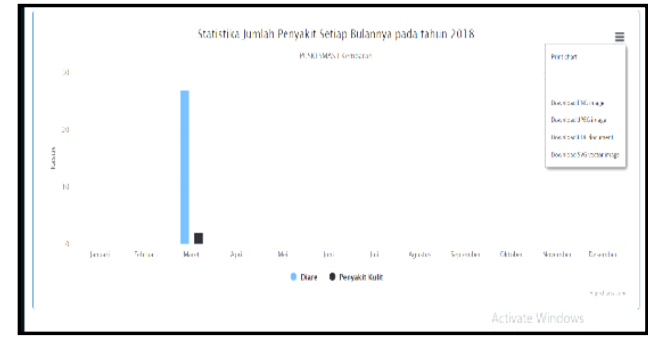

Gambar 4.47 Tampilan Halaman

Dashboard - Grafik Bar Pada Website

AKSI PINTAR (Analisis Klinik Sanitasi Pintar)

\section{Penerapan dan Evaluasi Sistem Pengolahan Data Klinik Sanitasi Penyakit Diare Berbasus Website}

Kegiatan penelitian penerapan Kegiatan penelitian penerapan website AKSI PINTAR (Analisis Klinik Sanitasi Pintar) untuk pengolahan data klinik sanitasi khususnya pada penyakit diare di Puskesmas 1 Kembaran dilakukan selama tiga minggu. Pada minggu pertama petugas klinik sanitasi diajarkan terlebih dahulu cara menginput dan memproses data pemeriksaan dan inspeksi lapangan (kunjungan lapangan) menggunakan website. Kemudian petugas akan melakukan input data pemeriksaan dan inspeksi lapangan sendiri. Pada minggu kedua, petugas diajarkan cara output data pemeriksaan dan inspeksi lapangan (kunjungan lapangan) yang sudah petugas klinik sanitasi lakukan. Kemudian petugas akan melakukan output data pemeriksaan dan inspeksi lapangan sendiri. Pada minggu ketiga petugas melakukan input, proses dan output data sendiri tanpa dibimbing oleh peneliti.

Dari hasil penelitian yang dilakukan, petugas dapat melakukan kegiatan input dan proses data klinik sanitasi baik pada pemeriksaan (pelaksanaan klinik sanitasi dalam gedung) maupun pada inspeksi lapangan (pelaksanaan klinik sanitasi luar gedung). Pada pelaksanaan output data, petugas dapat melakukan output data berupa table hasil pemeriksaan maupun inspeksi lapangan, diagram batang dan lingkaran dan foto hasil kunjungan yang petugas butuhkan dalam laporannya. Namun pada pelaksanaan output petugas masih melihat buku pedoman cara menggunakan website AKSI PINTAR.

Menurut petugas klinik sanitasi, dengan menggunakan website AKSI PINTAR petugas merasa terbantu dalam pelaksanaan kegiatan klinik sanitasi. Pada bagian input petugas merasa tidak perlu untuk mengisi dan menyalin formulir data pasien klinik sanitasi ke buku laporan klinik sanitasi dengan cara tulis tangan. Formulir yang ada pada website AKSI PINTAR juga sudah sesuai dengan Pemenkes No. 13 Tahun 2015. Pada pelaksanaan input data pasien klinik sanitasi di luar gedung (inspeksi lapangan), dengan adanya website AKSI PINTAR petugas merasa terbantu karena tidak perlu lagi membawa buku pedoman. Hanya tinggal membuka website melalui handphone, menginput data pasien dan menyimpannya. Petugas juga dapat mengambil dokumentasi berupa foto pada pelaksanaan inspeksi lapangan (kunjungan lapangan).

Pada bagian proses, petugas tidak lagi melakukukan kegiatan perhitungan data secara manual yang memungkinkan terjadinya kesalahan dalam perhitungan data. Dengan menggunakan website AKSI PINTAR, petugas hanya melakukan input data saja. Semua data yang masuk sudah otomatis tersimpan dan diolah. Data diolah dengan menggunakan PHP dan MySQL.

Pada bagian ouput, petugas terbantu dalam membuat laporan klinik sanitasi. dengan cepat dan mudah secara efektif dan efisien. Kegiatan pelaporan klinik sanitasi dilakukan sesuai dengan Permenkes No. 13 Tahun 2015. Petugas dapat dengan cepat dan mudah menyampaikan laporan pelaksanaan kegiatan klinik sanitasi secara berkala kepada Kepala Puskesmas atau Kepala Dinas Kesehatan Kabupaten/ Kota untuk digunakan sebagai bahan pengambilan keputusan.

Pada website AKSI PINTAR, semua data klinik sanitasi yang sudah terinput dapat terdokumentasi dengan baik tanpa takut data hilang atau terselip. Data yang terinput tersimpan secara online (hosting). Dengan begitu semua data klinik sanitasi setiap tahunnya akan tersimpan secara rapi. Hasil pemantauan dan evaluasi digunakan untuk mengukur kinerja Pelayanan Kesehatan Lingkungan di Puskesmas yang sekaligus menjadi indikator dalam penilaian akreditasi Puskesmas.

Hasil penelitian yang dilakukan oleh Ervian Adhe Candra Perwira (2014) di Puskesmas Ngawen dan Puskesmas Jogonalan Kabupaten Klaten, penerapan 
SIMPUS (Sistem Informasi Puskesmas) dengan menggunakan pernagkat lunak berbasis website bisa membantu dalam pelaksanaan kegiatan di puskesmas. Antara lain dalam hal pengelolaan data dasar puskesmas, pengelolaan data pemeriksan, pengelolaan data pelaporan, pengelolaan data survei yang dilakukan oleh puskesmas dan bagi masyarakat bisa mempermudah dalam pencarian informasi mengenai keberadaan dokter yang sedang bertugas di puskesmas atau yang sedang izin. Dengan adanya SIMPUS ini diharapkan manajemen puskesmas bisa menjadi lebih baik.

Berdasarkan hasil penelitian Prihandoko Eko Putro dan Berliana Kusuma Riasti (2012) dengan adanya aplikasi JKRS (Jaminan Kesehatan Rembang Sehat) berbasis website membantu petugas administrasi sehingga proses pendaftaran pasien penerima tunjangan lebih efektif dan efisien. Aplikasi JKRS berbasis web tersebut mempermudah petugas dalam penyimpanan berkas dan pencarian data. dapat membantu dinas kesehatan untuk menyalurkan bantuan atau jaminan kesehatan secara tepat, tanpa adanya manipulasi data.

D. Penginstalan Website AKSI PINTAR Website AKSI PINTAR dalam penggunaanya tidak perlu untuk dilakukan kegiatan pengintalan sistem. Petugas hanya masuk kedalam website AKSI

https://banyu.center/client/sanitasi

dengan menggunakan username dan password yang sudah dimiliki oleh petugas klinik sanitasi. Petugas klinik sanitasi di setiap puskesmas akan memiliki username dan password sendiri.

\section{E. Kelemahan Penelitian}

Kelemahan dalam penelitian ini adalah website AKSI PINTAR belum bisa mengakomodir pengolahan terhadap semua data penyakit berbasis lingkungan (PBL) hasil identifikasi ataupun kunjungan lapangan. Penelitian ini masih berfokus pada penyakit diare saja, yang merupakan penyakit dominan berbasis lingkungan (PBL) di Puskesmas 1 Kembaran.

Saran yang diberikan oleh petugas tentang aplikasi website AKSI PINTAR adalah hasil pemeriksaan untuk lebih di ringkas. Pada kolom pasien langsung berisi semua saran yang diberikan. Saran pada pasien diusahakan jangan muncul satu persatu, namun muncul pada kolom pasien yang sama.

\section{Simpulan dan Saran}

A. Simpulan

1. Website AKSI PINTAR atau Analisis Klinik Sanitasi Pintar merupakan website yang berfungsi untuk pengolahan data klinik sanitasi yang dilakukan secara online di puskesmas maupun di lapangan. Data klinik sanitasi yang diolah adalah data penyakit berbasis lingkungan. Website AKSI PINTAR dibuat dengan menggunakan MySQL dan PHP.

2. Penelitian dilakukan selama tiga minggu. Pada minggu pertama petugas diajarkan cara menginput dan memproses data klinik sanitasi menggunakan website AKSI PINTAR. Pada minggu kedua petugas diajarkan cara megoutput data klinik sanitasi menggunakan website AKSI PINTAR. Dan pada minggu ketiga petugas melakukan kegiatan input, proses dan output data sendiri tanpa dibimbing oleh peneliti.

3. Dari penelitian yang telah dilakukan, petugas dapat melakukan kegiatan input, proses dan output data klinik sanitasi baik pada pemeriksaan maupun pada inspeksi lapangan pada data klinik sanitasi penyakit diare menggunakan website AKSI PINTAR. Menurut petugas klinik sanitasi, dengan menggunakan website AKSI PINTAR petugas sangat terbantu dalam pelaksanaan kegiatan klinik sanitasi khususnya pada pengolahan data klinik sanitasi karena pertanyaan dan formulir laporan pada website sudah sesuai dengan Permenkes No. 13 Tahun 2015. Petugas juga merasa terbantu dalam kegiatan inspeksi lapangan karena tidak perlu lagi membawa buku pedoman klinik sanitasi

B. Saran

1. Petugas Puskesmas

Menerapkan website AKSI PITAR pada pelaksanaan pengolahan data klinik sanitasi di Puskesmas 1 
Kembaran secara berkala sehingga petugas klinik sanitasi dalam dapat mengolah data klinik sanitasi secara berkala, cepat, tepat dan mudah.

2. Kepala Puskesmas

Mengadvokasi kepada Kepala Dinas Kesehatan Kabupaten Banyumas untuk website AKSI PINTAR digunakan pada kegiatan klinik sanitasi di seluruh Puskemas Kabupaten Banyumas

3. Dinas Kesehatan Kabupaten Banyumas

a.Wajib melakukan monitoring pelaksanaan kegiatan klinik sanitasi sehingga PBL (Penyakit Berbasis Lingkungan) yang terjadi dapat turun sebagai dampak dari pelaksaaan klinik sanitasi di puskesmas.

b. Dapat membuat rencana tindak lanjut pelaksanaan klinik sanitasi.

c.Mengupayakan kebijakan pembaruan sumber internet di puskesmas.

d. Website AKSI PINTAR dapat terintegrasi ke dalam SIMPUS (Sistem Informasi Manajemen Puskesmas)

4. Peneliti lain

Website ini diharapkan dapat dikembangkan penerapannya pada seluruh penyakit berbasis lingkungan (PBL) yang merupakan sasaran dari pelaksanaan klinik sanitasi

\section{Daftar Pustaka}

Abdul Kadir, 2013, Pengertian MySQL, Yogyakarta: Mediakom.

Agus Heryanto, 2010, Aplikasi Pelayanan Puskesmas Berbasis Web (Studi Kasus Puskesmas Kecamatan Meja), Jakarta : Program Studi Teknik Informatika Fakultas Sains dan Teknologi Universitas Islam Negeri Syarif Hidayatullah.

Anhar, 2010, Panduan Menguasai PHP, and MySQL Secara Otodidak, Jakarta: Media Kita.

Ali Zaki, 2008, 36 Menit Belajar Komputer PHP dan MySQL. Jakarta: PT. Elex Media Komputindo.

Dinas Kesehatan Kabupaten Banyumas, 2016, Profil Kesehatan Kabupaten Banyumas, Purwokerto.
Dinas Kesehatan Propinsi Jawa Tengah, 2005, Standar Prosedur Operasional Klinik Sanitasi Untuk Puskesmas, Jakarta

Departemen Kesehatan RI, 2004, Kebijakan Dasar Pusat Kesehatan Masyarakat, PERMENKES RI No. 128 Tahun 2004.

Departemen Kesehatan RI, 2001, Panduan Konseling Bagi Petugas Klinik Sanitasi di Puskesmas, Jakarta: Ditjen PPM \& PL.

Departemen Kesehatan RI, 2002, Panduan Konseling Bagi Petugas Klinik Sanitasi di Puskesmas, Jakarta: Depkes RI.

Departemen Kesehatan RI, 2011, Petunjuk Teknis Sistem Informasi Kesehatan, Jakarta.

Departemen Kesehatan RI, 2014, Pusat Kesehatan Masyarakat, PERMENKES RI No. 75 Tahun 2014.

Departemen Kesehatan RI, 2015, Penyelenggaraan Pelayanan Kesehatan Lingkungan, PERMENKES RI No. 13 Tahun 2015.

Departemen Kesehatan RI, 1997, Petunjuk Teknis Pengembangan Sistem Informasi Manajemen Kesehatan Lingkungan, Jakarta : DITJEN. PPM \& PLP.

Ervian Adhe Candra Perwira; Kushartantya; Ragil Saputra, 2014, Sistem Infromasi Manakem Puskesmas (Studi Kasus: Puskesmas Ngawen dan Puskesmas Jogonalan Kabupaten Klaten), Journal Of Informatics and Technologi

Haris Saputro, 2012, Modul Pembelajaran Praktek Basis Data (MySQL), Jakarta : Elex Media Komputindo.

Hendrawan Hendrawan; Agus Nugroho; M. Roni Safirman, 2017, Perancangan Sistem Aplikasi Rekam Medis Pada Puskesmas Pakuan Baru Kota Jambi, Jambi : STIKOM Dinamika Bangsa.

Ivan Tinarbudi Gavinov dan J.F. Nervan Soemantri, 2016, Sistem Informasi Kesehatan, Jakarta : Parama Publishing.

Lia Kuswayatno, 2006, Mahir Berkomputer, PT. Grafindo Media Pratama.

Peraturan Pemerintah RI, 2014, Sistem Informasi Kesehatan, PP RI No. 46 Tahun 2014.

Puskesmas 1 Kembaran, 2016, Profil Puskesmas 1 Kembaran, Purwokerto. 
Prihandoko Eko Putro; Berlian Kusuma Riasti, 2012, Pembangunan Sistem Informasi Jaminan Kesehatan Rembang Sehat Berbasis Web Pada Dinas Kesehatan Kabupaten Rembang, SpeedSentra Penelitian Engineering dan Edukasi.

Rahmat Hidayat, 2010, Cara Praktis Membangun Website Gratis, Jakarta : Elex Media Komputindo.

Riani Eka Sari, 2015, Sistem Informasi Administrasi Pasien Rawat Jalan dan Rawat Inap Berbasis Web Pada Puskesmas Tanjung Raja, Palembang : Progra Studi Sistem Informasi Universitas Islam Negeri Raden Fatah Palembang.

Setyawan Wibisono; Siti Munawaroh, 2012, Sistem Informasi Manajemen Puskesmas (Simpuskesmas) berbasis Cloud Computing, Fakultas Teknologi Informasi : Unversitas Stikubank. Dinamik-Jurnal Teknologi Informasi.

Tri Cahyono, 2014, Pedoman Penulisan Proposal Penelitian dan Karya Tulis Ilmiah/ Skripsi, Purwokerto : Kesehatan Lingkungan Purwokerto.

Wahana Komputer, 2010, Panduan Belajar MySQL Database Server, Jakarta: Media Kita

Widoyono, 2005, Penyakit Tropis Epidemiologi, Penularan, Pencegahan dan Pemberantasannya, Semarang: Erlangga.

Wirasto S. Karim, 2012, Pemrogaman Web, Gorontalo : UNG.

Zulkifli Amsyah, 2005, Manajemen Sistem Informasi, Jakarta : Gramedia Pustaka Utama.

http://www.kompasiana.com/swift2016/apa-ituwebsite-danmanfaatnya 590adcb2dc22bd1b40f257bf, diakses tanggal 27 April 2017 pukul 19.00 WIB.

http://www.kesehatan.kebumenkab.go.id, diakses tanggal 25 November 2017 Pukul 20.00 WIB. 